\title{
Evaluation of the Antiinflammatory and Phospholipase-inhibitory Activity of Calpactin II/Lipocortin I
}

J. K. Northup, ${ }^{\star 5}$ K. A. Valentine-Braun,, Lorin K. Johnson," D. L. Severson, ${ }^{\star 5}$ and M. D. Hollenberg ${ }^{* 5}$

${ }^{*}$ Cell Regulation and ${ }^{\ddagger}$ Endocrine Research Groups, ${ }^{\S}$ Department of Pharmacology and Therapeutics, Faculty of Medicine,

University of Calgary, Calgary, Alberta T2N 4N1, Canada; and "California Biotechnology, Inc., Mountain View, California 94043

\begin{abstract}
We have examined the ability of a highly purified $38-\mathrm{kD}$ phospholipase-inhibitory protein (p38) isolated from human placental membranes that is also a preferred substrate for the epidermal growth factor-urogastrone (EGF-URO) receptor/ kinase, to block the release of arachidonate from zymosanstimulated murine peritoneal macrophages in vitro and to exhibit antiinflammatory activity in a carrageenin rat paw edema test in vivo. The ability of glucocorticoids to increase the amounts of this protein in macrophage cultures was also examined. p38 represents the naturally occurring, intact, $\mathbf{N H}_{2}$-terminally blocked human placental form of the protein termed calpactin II (or lipocortin I), for which partial amino acid sequence data and a complete amino acid sequence deduced from cDNA analysis have been reported. Our data demonstrated that, whereas p38 was an effective inhibitor of pancreatic phospholipase $A_{2}$ in vitro, it was unable to inhibit either the release of arachidonate from cultured zymosan-stimulated mouse peritoneal macrophages or inflammation in a rat paw edema test. At comparatively high protein concentrations, p38 enhanced either arachidonate release from intact macrophages in vitro $(0.5-10 \mu \mathrm{g} / \mathrm{ml})$ or carrageenin-induced paw swelling in vivo ( 2.5 or $25 \mu \mathrm{g}$ per injection). Furthermore, we were unable to detect induced amounts of p38 in cultures of glucocorticoidtreated peritoneal macrophages obtained from either mice or rats. Our data indicate that the antiphospholipase activity of p38 in vitro and the ability of p38 to serve as a receptor/kinase substrate may in no way relate to the putative ability of the protein to modify eicosanoid release from macrophages in vivo, so as to modulate the inflammatory process. Our data also raise the possibility that $\mathrm{p38}$ (calpactin II) may not be a true representative of the lipocortin family of glucocorticoid-inducible antiinflammatory proteins, despite its ability to inhibit phospholipase $A_{2}$ in vitro.
\end{abstract}

\section{Introduction}

Recent work has identified a $35-38-\mathrm{kD}$ substrate $(\mathrm{p} 38)^{1}$ for the protein tyrosine kinase receptor for epidermal growth factor-

These data were presented in part at the 1987 Annual Meeting of the American Federation for Clinical Research (1987. Clin. Res. 35:639a. [Abstr.]).

Address reprint requests to Dr. M. D. Hollenberg, Department of Pharmacology and Therapeutics, 3330 Hospital Drive, N. W., Calgary, Alberta T2N 4N1, Canada. 1988.

Received for publication 13 April 1987 and in revised form 1 June

J. Clin. Invest.

(C) The American Society for Clinical Investigation, Inc.

$0021-9738 / 88 / 10 / 1347 / 06 \$ 2.00$

Volume 82, October 1988, 1347-1352 urogastrone (EGF-URO) in A431 cells (1, 2), porcine lung (3), and human placenta (4-7). The partial sequencing of the EGF-URO receptor/kinase substrate has indicated that it is probably the same protein identified as a phospholipase-inhibitory protein from human U937 lymphoma cells, for which the entire cDNA sequence has been determined (8). Because of the ability of the U937 lymphoma cell protein to inhibit phospholipase $\mathrm{A}_{2}\left(\mathrm{PLA}_{2}\right)$ activity measured in vitro, it has been assumed (and widely accepted) that the U937 protein is representative of a group of glucocorticoid-inducible antiinflammatory proteins termed lipocortins, which are thought to play a role in the action of antiinflammatory steroids (9-13). Such glucocorticoid-inducible proteins, partially purified from a variety of sources, have been observed to inhibit the release of arachidonate metabolites, including prostaglandins, from intact cells (14-17) and to exhibit antiinflammatory activity in vivo in the carrageenin paw edema test (18). Although the U937 protein was never shown to be either antiinflammatory or glucocorticoid inducible, it was designated as lipocortin I on the basis of its phospholipase-inhibitory activity in vitro (8). The sequence of this protein is distinct, but closely related to that of the 36-kD substrate (p36) of the sarcoma virus tyrosine kinase (pp60 src-kinase) (19). Because of their ability to bind to actin in the presence of calcium and phospholipid, these proteins have been termed calpactins (19-21); the human placental substrate for pp $60^{\mathrm{src}}$ has been termed calpactin I, whereas the placental substrate (p38) for the EGF-URO receptor/kinase has been termed calpactin II (6). Because of its phospholipase-inhibitory activity, calpactin I has also been assumed to represent a member of the lipocortin family, and calpactin I thus has also been designated in the literature as lipocortin II (6). In view of the lack of information about the glucocorticoid inducibility and antiinflammatory activity of the calpactins, we wondered if the term "lipocortin" might be a misnomer for these actin-binding proteins that are by now also widely recognized as lipocortins I and II in the literature.

It is now apparent that the inhibition of pancreatic PLA $\mathrm{A}_{2}$ in vitro by either calpactin I or II is due to substrate sequestration and not to a direct enzyme-inhibitor interaction (22). Furthermore, no data have yet emerged showing that the recombinant calpactins can directly inhibit the cellular release of AA or the development of an inflammatory response evoked under physiologically relevant conditions in response to specific stimuli, or that the protein designated lipocortin I (calpactin II) can be induced by steroids in macrophage cell culture systems. Published data do, however, document the ability of recombinant human lipocortin I (calpactin II) to reduce the release of pros-

\footnotetext{
1. Abbreviations used in this paper: EGF-URO, epidermal growth factor-urogastrone; $\mathrm{p} 38,38-\mathrm{kD}$ protein representing lipocortin I/calpactin II; PLA $A_{2}$, phospholipase $A_{2} ;$ pp $60^{\text {src }}$ kinase, tyosine kinase from sarcoma virus.
} 
tacyclin from suspensions of human umbilical artery rings (23) and to block the release of thromboxane from perfused guinea pig lung (24) when triggered by some agonists (e.g. leukotriene $\mathrm{C}_{4}\left[\mathrm{LTC}_{4}\right]$ or chemotactic tripeptides) but not by others (e.g. bradykinin).

The main question leading to this study was: does the substrate for the EGF-URO receptor/kinase (p38/calpactin II) truly represent the family of glucocorticoid-inducible antiinflammatory proteins, termed lipocortins? In view of this question, we examined the ability of an intact, highly purified phospholipase-inhibitory preparation of human placental p38/calpactin II, which we $(4,5)$ and others have isolated $(6$, 7), to block the release of arachidonate from zymosan-stimulated mouse peritoneal macrophages in vitro and to exhibit antiinflammatory activity in a carrageenin paw edema test in vivo. Our data indicate that although p38/calpactin II is an inhibitor of pancreatic PLA $_{2}$ in vitro, it does not inhibit the release of arachidonate from zymosan-stimulated macrophages under conditions in which corticosteroids are effective. It also does not exhibit antiinflammatory activity in the paw edema assay in vivo (it promotes rather than inhibits swelling). Furthermore, the synthesis and release of p38/calpactin II from either mouse or rat peritoneal macrophages was not induced by corticosteroid treatment of the cells in vitro.

\section{Methods}

Protein purification and characterization. Homogeneous p38 was isolated from human placental membranes by a procedure described in more complete detail elsewhere (5). Placenta membranes were purified from fresh-term human placentas (obtained by cesarean section), using a differential centrifugation protocol previously described $(4,25)$, with minor modifications. $\mathrm{CaCl}_{2}$ and protease inhibitors (0.2 mM PMSF, $25 \mathrm{mM}$ benzamidine, and $2 \mu \mathrm{g} / \mathrm{ml}$ each of leupeptin, soybean trypsin inhibitor, and aprotinin) were included in the homogenization buffer. The isolation of the membranes in the presence of $\mathrm{CaCl}_{2}$ and protease inhibitors yielded a preparation containing, predominantly, a 38-kD substrate for the EGF-URO receptor/kinase, along with smaller amounts of a $35-\mathrm{kD}$ substrate that we have observed previously (4). In brief, the protein isolation protocol, which was completed within a 72-h period at $4^{\circ} \mathrm{C}$, was as follows: p38 was dissociated from the membranes in the presence of $5 \mathrm{mM}$ EGTA, and was purified by sequential chromatography on DEAE-Sephacel (Pharmacia Fine Chemicals, Piscataway, NJ [the unadsorbed protein fraction was collected]) and on carboxymethyl (CM)-Sepharose CL-6B. Elution of the $\mathrm{CM}$-Sepharose column with $\mathrm{NaCl}$ yielded the 38-kD receptor/kinase substrate (p38) as a single-protein peak that was homogeneous on gel electrophoretic analysis and that contained a single immunoreactive band when assayed with either anti-transducin antibodies or with anti-p38 antibodies. Details concerning the methods for characterizing p38 are outlined in the legend to Fig. 1, in Results and in more detail elsewhere (5).

Phospholipase-inhibitory activity and macrophage arachidonate release assay. The ability of $\mathrm{p} 38$ to inhibit porcine pancreatic PLA $_{2}$ (Sigma Chemical Co., St. Louis, MO) activity was evaluated in vitro using either $\left[{ }^{14} \mathrm{C}\right]$ oleate-labeled Escherichia coli or synthetic radiolabeled phospholipid (1-palmitoyl-2-[1-14 C]olelyl-phosphatidyl choline, $10 \mu \mathrm{M})$ as enzyme substrate (26-28). The details of the individual phospholipase experiments are recorded in Results and in the legend to Fig. 2. Arachidonate release from zymosan-stimulated mouse resident peritoneal macrophages, which had been prelabeled for $16 \mathrm{~h}$ with $\left[{ }^{14} \mathrm{C}\right]$-labeled arachidonate, was measured after $45 \mathrm{~min}$ of zymosan stimulation; details of individual experiments are recorded both in Results and in the legend to Fig. 3. Radioactivity released into the supernatant and in the cell layer was determined and the percent release stimulated by zymosan was calculated.
Western blotting of proteins from glucocorticoid-treated macrophages. Mouse peritoneal macrophages prepared in parallel with those used for AA release experiments were either treated or not with $0.1 \mu \mathrm{M}$ dexamethasone for $3 \mathrm{~h}$ under serum-free conditions. Similarly harvested rat peritoneal macrophages were cultured either with or without $10 \% \mathrm{FCS}$ in the presence or absence of $1 \mu \mathrm{M}$ hydrocortisone for $2 \mathrm{~h}$ at $37^{\circ} \mathrm{C}$. Protein appearing in the culture media was collected and concentrated by precipitation with $10 \%$ TCA. The cell layers and media proteins were solubilized in SDS sample buffer and fractionated on a $12.5 \%$ acrylamide gel in SDS. After blotting to nitrocellulose, immunoreactive protein was detected using antibodies raised to purified human placental p38 (5). These antibodies can detect as little as $0.1 \mathrm{ng}$ of $\mathbf{p} 38$.

Paw edema assay. Carrageenin-induced paw edema was measured in male Sprague-Dawley rats after the administration under the footpad of $0.1 \mathrm{ml}$ of a $0.5 \% \mathrm{wt} / \mathrm{vol}$ carrageenin solution in saline either in the absence or presence of coadministered test sample, as outlined in the legend to Fig. 3. Saline alone $(0.1 \mathrm{ml})$ was administered as a control, against which average paw thickness was measured, using calipers, in millimeters at timed intervals.

\section{Results}

As indicated in Fig. 1, our procedure yielded p38 that was homogeneous according to gel electrophoresis (Fig. 1, lane 1) and contained no minor degradation products, as indicated by the presence of a single immunoreactive species, using either an anti-transducin antibody or antibody prepared against purified receptor kinase substrate (reference 5 and data not shown). As is also shown in Fig. 1, p38 was a good substrate for the receptor/kinase in a placenta membrane reconstitution system $(4,5)$. This protein, which had a blocked $\mathrm{NH}_{2}$-terminus, had an amino acid composition equivalent to that deduced from the cloned cDNA sequence reported for lipocortin I (8), and yielded a $35-\mathrm{kD}$ proteolytic product for which partial amino-terminal sequencing (5) yielded a sequence identical to amino acid residues 13-36 deduced from the cloned cDNA sequence of lipocortin I (8). This sequence differs only slightly from that of the homologous protein isolated from porcine lung (3). The 35-kD species, representing the proteolytic cleavage product of $\mathrm{p} 38$, has been described in a number of previous studies $(1,3,4)$. Our data were entirely in accord with the information obtained independently by Haigler and coworkers (7) for purified human placental calpactin II/lipocortin I. We thus conclude that the p38 used for our studies represents a highly purified, intact, naturally occurring human placental form of the cloned protein, termed calpactin II/lipocortin I $(2,6)$.

Zymosan-stimulated arachidonate release and phospholipase-inhibitory activity. p38 was able to inhibit porcine pancreatic $\mathrm{PLA}_{2}$ in a concentration-dependent manner using radiolabeled $E$. coli as substrate (Fig. 2). In addition to inhibiting pancreatic $\mathrm{PLA}_{2}$ when radiolabeled $E$. coli were used as substrate (Fig. 2), p38 was also able to inhibit the activity of the enzyme when a synthetic radiolabeled phospholipid (26) (1palmitoyl-2-[1-14 C]oleoyl-phosphatidyl choline, $10 \mu \mathrm{M})$ was used as a substrate in $50 \mathrm{mM}$ [1,4-piperazinebis(ethane sul-

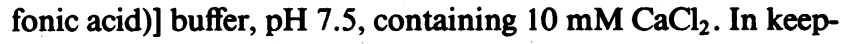
ing with the $E$. coli assay $(27,28)$, the enzyme (1 $\mathrm{ng})$ was routinely preincubated for $20 \mathrm{~min}$ at $4^{\circ} \mathrm{C}$ with p38 (2 $\mu$ g; final volume, $100 \mu \mathrm{l}$ ) before initiating the reaction by the addition of substrate $(10 \mu \mathrm{M}$ in a final volume of $200 \mathrm{ml})$. Hydrolysis was allowed to proceed for $30 \mathrm{~min}$ at $30^{\circ} \mathrm{C}$, at which time the reaction was stopped by the addition of $3 \mathrm{ml}$ of isopropanol/ 


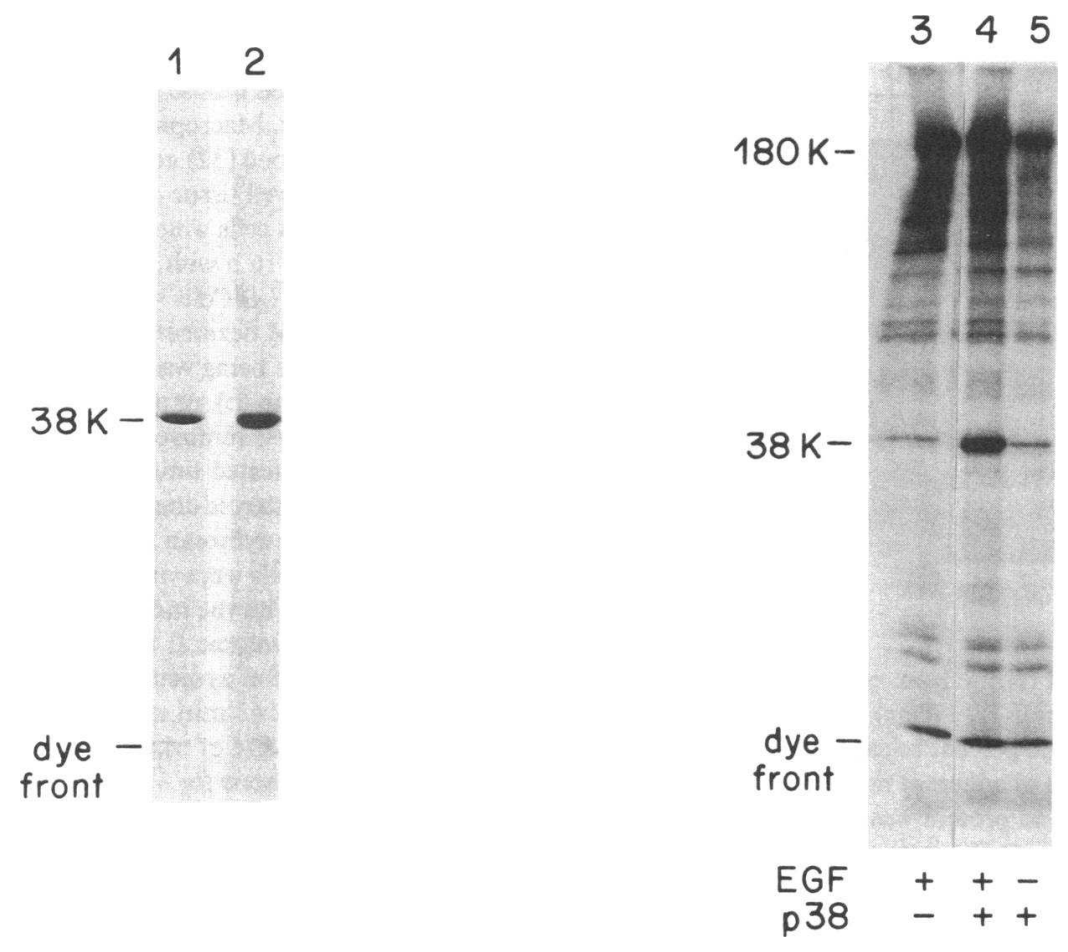

Figure 1. Electrophoretic and immunoblot analysis of p38. Protein isolated as outlined in the text and detailed elsewhere (5) was analyzed by SDS-PAGE (31). $2 \mu \mathrm{g}$ protein was either stained directly (Coomassie Brilliant Blue stain, lane 1) or was transferred to nitrocellulose for immunoblot detection (lane 2) using anti-transducin antibodies, as previously described $(4,5)$. The autoradiogram (lanes 3-5) shows the EGF-URO-dependent phosphorylation of $\mathrm{p} 38$ $(0.2 \mu \mathrm{g})$ in a placenta membrane reconstitution system; the presence or absence of EGF-URO and p38 is indicated at the bottom of the autoradiogram. The transducin preparation protocol used in connection with antibody production yielded protein free $(<1 / 10,000$ [5]) from $\mathrm{p} 38$, as judged by Western blot analysis using anti-p38 antibodies. The EGF-UROdependent phosphorylation of p38 (lane 4) was done using a placenta membrane reconstitution system, as described $(4,5)$. The position of $\mathrm{p} 38$ is indicated by an arrow (38K). heptane (1:1 vol/vol), $1.1 \mathrm{ml} \mathrm{H}_{2} \mathrm{O}$, and $0.2 \mathrm{ml} 0.1 \mathrm{M} \mathrm{H}_{2} \mathrm{SO}_{4}$. Residual unhydrolyzed substrate in an $0.8-\mathrm{ml}$ sample of the upper phase was removed by adsorption to $5 \mathrm{mg}$ silicic acid, and $\left[{ }^{14} \mathrm{C}\right]$ oleate in an $0.5-\mathrm{ml}$ aliquot of the silicic acid-treated upper phase was measured by scintillation counting. Under these assay conditions, $10 \mu \mathrm{g} / \mathrm{ml} \mathrm{p} 38$ caused a $32 \pm 3 \%$ (mean \pm SEM; $n=4$ ) inhibition of enzyme activity; maximally, we observed enzyme inhibition of $\sim 54 \%$ at concentrations of p38 $>16 \mu \mathrm{g} / \mathrm{ml}$. This degree of inhibition would have been increased by reducing the amount of phospholipid substrate relative to $\mathrm{p} 38$ in the assay (22). The inhibitory action of $\mathrm{p} 38$ was observed over the time course of the enzyme assay, whether or not the $\mathrm{PLA}_{2}$ had been preincubated with $\mathrm{p} 38$ before the initiation of the reaction by the addition of substrate.

In contrast to the above results obtained in vitro, p38 did not cause an appreciable inhibition of arachidonate release from intact zymosan-stimulated macrophages (Fig. $3 \mathrm{~B}$ ); if anything, at higher concentrations $(0.5-10 \mu \mathrm{g} / \mathrm{ml}), \mathrm{p} 38$ caused a significant increase in arachidonate release from intact macrophages. This increase in arachidonate release, seen at higher input concentrations of $\mathrm{p} 38$, was not due to contaminating endotoxin. As measured by the limulus assay, the p38 preparations used showed $<0.1 \mathrm{U} / \mu \mathrm{g}$ protein. In addition, control experiments using an input of $1 \mathrm{U}$ of endotoxin per macrophage assay well failed to stimulate the release of arachidonate over the unstimulated background level (data not shown). In contrast with the inability of $\mathrm{p} 38$ to block arachidonate release from intact macrophages, dexamethasone markedly reduced arachidonate release in the macrophage test system (Fig. $3 B$ ).

For comparative purposes, the conditioned media of glucocorticoid-treated macrophages were also assayed for the ability to inhibit zymosan-induced arachidonate release (Fig. 3 A). Inhibitory activity appeared in the culture supernatants within 30 min of corticosteroid treatment and reached a tran- sient peak at $90 \mathrm{~min}$. A secondary increase in inhibitory activity appeared in the culture media after $9 \mathrm{~h}$, reaching maximal activity (34\% inhibition) at $21 \mathrm{~h}$. The rapid appearance of inhibitory activity in the culture media was similar to that described previously for macrocortin release from nonadherent peritoneal leukocytes (14). A more pronounced inhibitory effect of the steroid was observed when the treated cells were measured directly for arachidonate release (Fig. $3 \mathrm{~A}$, lower curve). In this case, zymosan-activated arachidonate release was inhibited by $70 \%$ after $21 \mathrm{~h}$ of steroid treatment.

To test whether the appearance of inhibitory activity in the supernatant correlated with the glucocorticoid-induced release of p38, the supernatant and cell-layer fractions were analyzed by Western blotting for the presence of immunoreactive $\mathrm{p} 38$.

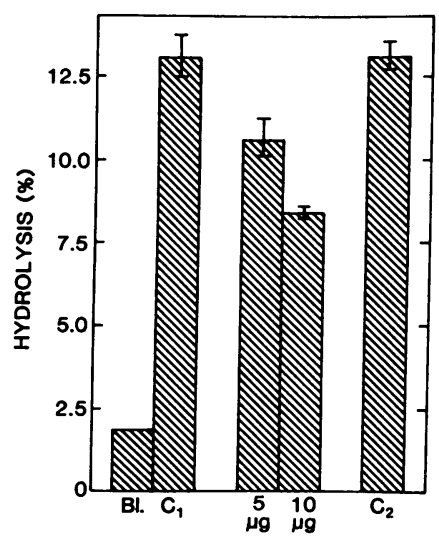

Figure 2. Phospholipase-inhibitory activity of $\mathrm{p} 38$. The ability of p38 to inhibit porcine pancreatic $\mathrm{PLA}_{2}$ using $\left[{ }^{14} \mathrm{C}\right]-$ oleate-labeled $E$. coli as substrate was assayed essentially as previously described ( 27 , 28). Hydrolysis in the presence of $100 \mathrm{ng}$ enzyme and increasing amounts of $\mathrm{p} 38$ ( 5 and 10 $\mu \mathrm{g})$ was allowed to proceed for $20 \mathrm{~min}$ at $4^{\circ} \mathrm{C}$. The hydrolysis of $\left[{ }^{14} \mathrm{C}\right]$ oleate (percent of total) was estimated by stopping the reaction with $100 \mu \mathrm{g}$ of BSA followed by separation of $E$. coli-bound and free ${ }^{14} \mathrm{C}$ by centrifugation. Radioactivity in both pellet and supernatant was then determined by scintillation counting. Bl., no enzyme; $C_{1}$ and $C_{2}$, enzyme alone; the amounts of p38 added to the enzyme assay are indicated below the middle two histograms. Values in this figure represent the means \pm SEM of triplicate estimates. 


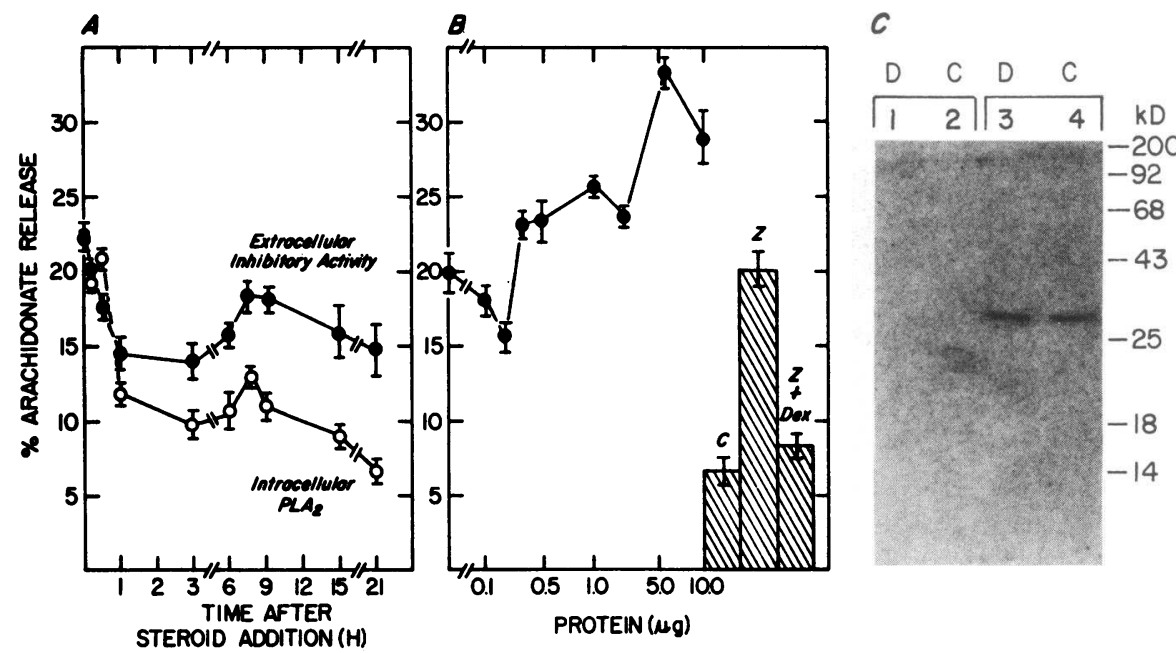

Figure 3. Effect of p38 and glucocorticoids on the release of AA (percent of cell total) from zymosan-stimulated mouse resident peritoneal macrophages. Macrophages were obtained as described (32) and allowed to adhere in 24-well tissue culture plates for $4 \mathrm{~h}$. Adherent cells were then washed and labeled for $16 \mathrm{~h}$ with $1 \mu \mathrm{Ci}$ $\left[{ }^{14} \mathrm{C}\right]$ arachidonate (32). $(A)$ Cells were either treated with $0.1 \mu \mathrm{M}$ dexamethasone for various times before being washed and stimulated with zymosan (0), or serum-free conditioned medium was removed from cells treated for the indicated times and was then added to nonsteroid-treated cultures for $15 \mathrm{~min}$ before zymosan stimulation (๑). (B) Labeled cells were washed and preincubated $15 \mathrm{~min}$ with the indicated amounts of $\mathrm{p} 38$ (final volume, $1 \mathrm{ml}$ ) before zymosan stimulation. The histograms show the background release from control cells not exposed to zymosan (C), the effect of zymosan alone $(Z)$, or cells treated $16 \mathrm{~h}$ with dexamethasone prior to zymosan $\left(Z+\right.$ Dex). In all cases, $\left[{ }^{14} \mathrm{C}\right]$ arachidonate in the media (after $45 \mathrm{~min}$ of zymosan stimulation) and in the cell layer was determined and the percent release was calculated. Values represent the means \pm SEM of triplicate determinations. (C) 60 -mm plates containing confluent layers of adherent macrophages were induced with $0.1 \mu \mathrm{M}$ dexamethasone for $3 \mathrm{~h}$ in 1.0 $\mathrm{ml}$ serum-free media. The supernatant was then collected and protein was precipitated by the addition of cold TCA to $10 \%$ (50 $\mu \mathrm{g}$ insulin was used as a coprecipitant). After the pellets were collected by centrifugation and acetone washed, they were solubilized in electrophoresis sample buffer, containing SDS. Cellular proteins were solubilized in $1 \%$ SDS $\left(100^{\circ} \mathrm{C}\right)$, quick cooled to $4^{\circ} \mathrm{C}$, digested with $1 \mu \mathrm{g} / \mathrm{ml} \mathrm{DNAse} \mathrm{I,} \mathrm{and} \mathrm{added}$ to an equal volume of $2 \times$ SDS sample buffer. Proteins from the media and cell layer were fractionated on a $12.5 \%$ SDS acrylamide gel (31) and processed for Western blotting as previously described (33). Lanes 1 and 2, media proteins from steroid-treated (D) and control cells (C). Lanes 3 and 4, cellular proteins from steroid-treated (D) and control cells (C).

As shown in Fig. $3 C$, glucocorticoid treatment did not cause an elevation of the intracellular quantities of p38, nor did it cause the appearance (release) of detectable p 38 immunoreactivity in the media. With this antibody, the detectable limit of p38 immunoreactivity is $0.1 \mathrm{ng}$. Since the total protein concentration in the macrophage-conditioned medium after $3 \mathrm{~h}$ was $\sim 1.0 \mu \mathrm{g} / \mathrm{ml}$, it follows that lipocortin, if it were secreted, would have been present at an abundance level of $<0.01 \%$. We were similarly unsuccessful in observing an effect of hydrocortisone on the levels of p38 in cultured rat peritoneal macrophages (data not shown).

In the carrageenin paw edema assay, $16 \mathrm{~h}$ dexamethasone pretreatment, as is recognized, was able to reduce paw swelling over the time period of the assay (Fig. 4). In this assay, $3 \mathrm{~h}$ after the administration of p38 at 2.5 and $25 \mu \mathrm{g}$ per paw, an apparent increase, rather than a decrease in paw thickness, was observed (Fig. 4). At lower concentrations, $0.1-1.0 \mu \mathrm{g} / \mathrm{paw}$, no increase or decrease in paw thickness was observed (data not shown).

\section{Discussion}

The data in Fig. 1, along with information that we (5) and others $(6,7)$ have published leave no doubt that the protein used for our studies (p38) was highly purified intact human placental calpactin II/lipocortin I, for which the entire amino acid sequence is known $(2,6)$. The reactivity of $p 38$ with the anti-transducin antibody indicated that the protein is the one we described previously as a substrate for the EGF-URO receptor/kinase (4) and that we have purified to homogeneity

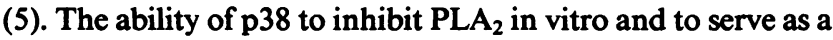
tyrosine kinase substrate in the reconstitution assay indicated (a) that the protein was obtained in its active phospholipase-inhibitory dephosphorylated form; and $(b)$ that the protein, upon isolation, had retained its ability to interact both with cell membranes and with the synthetic phospholipid/PLA 2 assay system in vitro. As the protein was obtained in a dephosphorylated state, one would have expected an inhibition of arachi-

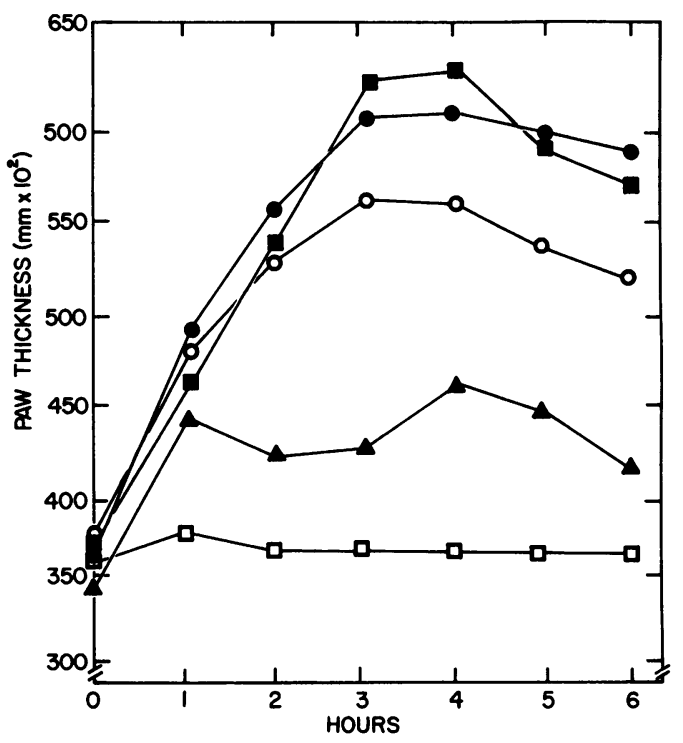

Figure 4. Paw edema assay. Carrageenin-induced paw edema was elicited as previously described (34) either in the absence or presence of coadministered agents; a carrageenin-free saline injection was used as a control (ם) against which average paw thickness (millimeters $\left.\times 10^{2}\right)$ was compared using calipers. 0 , carrageenin $(0.5 \%$ in saline) alone; $\Delta$, carrageenin plus $1 \mathrm{mg} / \mathrm{kg}$ dexamethasone given $16 \mathrm{~h}$ previously; •, carrageenin plus $25 \mu \mathrm{g}$ p38; e, carrageenin plus $2.5 \mu \mathrm{g}$ p38. The values shown are the means of measurements on six animals per group. 
donate release from intact cells wherein lipocortin phosphorylation, possibly by a tyrosine kinase, is thought to regulate its phospholipase-inhibitory activity $(29,30)$.

At first glance, our data might appear to contradict the observations of Flower and colleagues, who have used recombinant human lipocortin I to reduce the release of prostacyclin from human umbilical artery rings (23) or to block thromboxane release from perfused guinea pig lung (24). However, it should be noted that in those studies $(a)$ the inhibitory effects of recombinant lipocortin I on prostanoid production appeared to depend on the dose of the triggering agonist used (e.g., lipocortin I was inhibiting at low but not at high concentrations of $\left.\mathrm{LTC}_{4}\right)$ and $(b)$ that thromboxane release triggered by bradykinin was not blocked by lipocortin I. Our data, demonstrating that calpactin II (lipocortin I) cannot inhibit zymosan-stimulated arachidonate release or carageenin-stimulated paw edema, thus may indicate that many processes associated with an inflammatory response, including arachidonate release, can be triggered by stimuli distinct from those inhibited by lipocortin I in the guinea pig lung and in the aortic ring system. It is unfortunate that the recombinant lipocortin I preparations evaluated by Flower and colleagues were not also simultaneously assayed in the arachidonate-release and paw edema systems. What cannot be overlooked, however, is that in our work the glucocorticoid-induced factors recovered from the supernatant of the macrophage cultures (putative lipocortins) were capable of inhibiting zymosan-triggered arachidonate release (Fig. $3 \mathrm{~A}$ ), whereas p38 did not do so. P38 was not detected in increased amounts in either the supernatants or cell layers of glucocorticoid-treated macrophage cultures (Fig. $3 C$ ). The data thus suggest that p38/calpactin II does not represent the macrophage-derived, glucocorticoid-inducible, phospholipase-inhibitory factor(s) (lipocortin[s]) detected in the culture supernatants, despite the fact that the macrophages contain appreciable amounts of $p 38 /$ calpactin II. This conclusion is in keeping with the lack of any published information indicating that lipocortin I can be induced by glucocorticoids in macrophages, even though it is present in these cells and in a variety of other cell types $(3,6)$.

One alternative, but in our opinion a less likely explanation of our data, would be that the intact form of human $\mathrm{p} 38 / \mathrm{cal}$ pactin II that we have been able to isolate, using proteolysis inhibitors and a rapid sequential chromatographic protocol, must be partially cleaved or otherwise modified to yield material that would be active as a phospholipase-inhibitory agent in intact cells. Note that previous studies have identified lipocortin activity in protein fractions, ranging in molecular mass from 15 to $40 \mathrm{kD}(9-13)$. Further, it is possible (although unlikely) that $\mathrm{p} 38$, as obtained, may have undergone a modifcation leading to a change in the protein domain responsible for biological activity in intact cell systems, whilst retaining the activities of the domains responsible for internal plasma membrane association (kinase reconstitution assay) and PLA inhibition in vitro.

The possibilities outlined in the previous paragraph notwithstanding, our data indicate that intact human placental p38/calpactin II does not exhibit a number of characteristics that would qualify it as a member of the lipocortin family of proteins (9-13), apart from its ability to inhibit $\mathrm{PLA}_{2}$ in vitro: (a) it does not, under circumstances in which a glucocorticoid-induced macrophage culture supernatant does so, inhibit the release of arachidonate from cultured zymosan-stimulated macrophages; $(b)$ it does not exhibit antiinflammatory activity in a rat paw edema assay that responds to glucocorticoid treatment; and $(c)$ it is not induced by glucocorticoids in macrophage cultures that otherwise yield phospholipase-inhibitory material when treated with steroids. It thus would appear premature at this point in time to designate p38/calpactin II as lipocortin I. Clearly, the true physiological role for this interesting member of the annexin protein superfamily $(20,21)$ remains to be determined.

\section{Acknowledgments}

These studies were supported in part by grants from the Medical Research Council of Canada (to Dr. Northup and Dr. Hollenberg).

\section{References}

1. Fava, R. A., and S. Cohen. 1984. Isolation of a calcium-dependent 35-kilodalton substrate for the epidermal growth factor receptor/ kinase from A-431 cells. J. Biol. Chem. 259:2636-2645.

2. Pepinsky, R. B., and L. K. Sinclair. 1986. Epidermal growth factor-dependent phosphorylation of lipocortin. Nature (Lond.). 321:81-84.

3. De, B. K., K. S. Misono, T. J. Lukas, B. Mroczkowski, and S. Cohen. 1986. A calcium-dependent 35-kilodalton substrate for epidermal growth factor receptor/kinase isolated from normal tissue. $J$. Biol. Chem. 261:13784-13792.

4. Valentine-Braun, K. A., J. K. Northup, and M. D. Hollenberg. 1986. Epidermal growth factor (urogastrone)-mediated phosphorylation of a $35-\mathrm{kDa}$ substrate in human placental membranes: relationship to the $\beta$ subunit of the guanine nucleotide regulatory complex. Proc. Natl. Acad. Sci. USA. 83:236-240.

5. Valentine-Braun, K. A., M. D. Hollenberg, E. Fraser, and J. K. Northup. 1987. Isolation of a major human placental substrate for the epidermal growth factor (urogastrone) receptor kinase: immunological cross-reactivity with transducin and sequence homology with lipocortin. Arch. Biochem. Biophys. 259:262-282.

6. Huang, L. S., B. P. Wallner, R. J. Mattaliano, R. Tizard, C. Burne, A. Frey, C. Hession, P. McGray, L. I. Sinclair, E. P. Chow, J. L. Browning, K. L. Ramachandran, J. Tang, J. E. Smart, and R. B. Pepinsky. 1986. Two human $35 \mathrm{kd}$ inhibitors of phospholipase $A_{2}$ are related to substrates of pp60 $00^{\text {vsrc }}$ and of the epidermal growth factor receptor/kinase. Cell. 46:191-199.

7. Haigler, H. T., D. D. Schlaepfer, and W. H. Burgess. 1987. Characterization of lipocortin I and an immunologically unrelated 33-kd protein as epidermal growth factor receptor/kinase substrates and phospholipase $A_{2}$ inhibitors. J. Biol. Chem. 262:6921-6930.

8. Wallner, B. P., R. J. Mattaliano, C. Hession, R. L. Cate, R. Tizard, L. K. Sinclair, C. Foeller, E. P. Chow, J. K. Browning, K. L. Ramachandran, and R. B. Pepinsky. 1986. Cloning and expression of human lipocortin, a phospholipase $\mathrm{A}_{2}$ inhibitor with potential antiinflammatory activity. Nature (Lond.). 320:77-81.

9. Flower, R. J. 1984. Macrocortin and the antiphospholipase proteins. Adv. Inflamm. Res. 8:1-34.

10. Flower, R. J. 1985. Background and discovery of lipocortins. Agents Actions. 17:255-262.

11. Rothhut, B., and F. Russo-Marie. 1985. From renocortin to lipocortin. Adv. Inflamm. Res. 10:360-370.

12. Hirata, F. 1985. Biology of lipocortin and glucocorticoids in inflammatory disease. Adv. Inflamm. Res. 10:366-370.

13. Di Rosa, M., R. J. Flower, F. Hirata, L. Parente, and F. RussoMarie. 1984. Anti-phospholipase proteins. Prostaglandins. 28:441442.

14. Blackwell, G. J., R. Carnuccio, M. Di Rosa, R. J. Flower, L. Parente, and P. Persico. 1980. Macrocortin: a polypeptide causing the anti-phospholipase effect of glucocorticoids. Nature (Lond.). 287:147149. 
15. Carnuccio, R., M. Di Rosa, and P. Persico. 1980. Hydrocortisone-induced inhibitor of prostaglandin biosynthesis in rat leucocytes. Br. J. Pharmacol. 68:14-16.

16. Hirata, F., E. Schiffmann, K. Venkatasubramanian, D. Salomon, and J. Axelrod. 1980. A phospholipase $A_{2}$ inhibitory protein in rabbit neutrophils induced by glucocorticoids. Proc. Natl. Acad. Sci. USA. 77:2533-2536.

17. Cloix, J. F., O. Colard, B. Rothhut, and F. Russo-Marie. 1983. Characterization and partial purification of 'renocortins': two polypeptides formed in renal cells causing the antiphospholipase-like action of glucocorticoids. Br. J. Pharmacol. 79:313-321.

18. Blackwell, G. J., R. Carnuccio, M. Di Rosa, R. J. Flower, J. Ivanyi, C. S. J. Langham, L. Parente, P. Persico, and J. Wood. 1983. Suppression of arachidonate oxidation by glucocorticoid-induced antiphospholipase peptides. Adv. Prostaglandin Thromboxane Leukotriene Res. 11:65-71.

19. Saris, C. J. M., B. F. Tack, T. Kristensen, J. R. Glenney, Jr., and T. Hunter. 1986. The cDNA sequence for the protein-tyrosine kinase substrate p36 (calpactin I heavy chain) reveals a multidomain protein with internal repeats. Cell. 46:201-212.

20. Geisow, M. J., J. H. Walker, C. Boustead, and W. Taylor. 1987. Annexins: new family of $\mathrm{Ca}^{2+}$-regulated-phospholipid binding protein. Biosci. Rep. 7:289-298.

21. Hollenberg, M. D., K. A. Valentine-Braun, and J. K. Northup. 1988. Protein tyrosine kinase substrates: Rosetta stones or simply structural elements? Trends Pharmacol. Sci. 9:63-66.

22. Davidson, F. F., E. A. Dennis, M. Powell, and J. R. Glenney. 1987. Inhibition of phospholipase $A_{2}$ by "lipocortins" and calpactins. J. Biol. Chem. 262:1698-1705.

23. Cirino, G., and R. J. Flower. 1987. Human recombinant lipocortin I inhibits prostacyclin production by human umbilical artery in vitro. Prostaglandins. 34:59-62.

24. Cirino, G., R. J. Flower, J. L. Browning, L. K. Sinclair, and R. B. Pepinsky. 1987. Recombinant human lipocortin 1 inhibits thromboxane release from guinea-pig isolated perfused lung. Nature (Lond.). 328:270-272.

25. Hock, R. A., and M. D. Hollenberg. 1980. Characterization of the receptor for epidermal growth factor-urogastrone in human placenta membranes. J. Biol. Chem. 255:10731-10736.

26. Hee-chong, M., T. Fletcher, S. Kryski, and D. L. Severson. 1985. Diacylglycerol lipase and kinase activities in rat brain microvessels. Biochim. Biophys. Acta. 833:59-68.

27. Patriarca, P., S. Beckerdite, and P. Elsbach. 1972. Phospholipases and phospholipid turnover in Escherichia coli spheroplasts. Biochim. Biophys. Acta. 260:593-600.

28. Rothhut, B., F. Russo-Marie, J. Wood, M. Di Rosa, and R. J. Flower. 1983. Further characterization of the glucocorticoid-induced antiphospholipase protein "Renocortin". Biochem. Biophys. Res. Commun. 117:878-884.

29. Hirata, F. 1981. The regulation of lipomodulin, a phospholipase inhibitory protein, in rabbit neutrophils by phosphorylation. $J$. Biol. Chem. 256:7730-7733.

30. Hirata, F., K. Matsuda, Y. Notsu, T. Hattori, and R. Del Carmine. 1984. Phosphorylation at a tyrosine residue of lipomodulin in mitogen-stimulated murine thymocytes. Proc. Natl. Acad. Sci. USA. 81:4717-7421.

31. Laemmli, U. K. 1970. Cleavage of structural proteins during the assembly of the head of bacteriophage T4. Nature (Lond.). 227:680-685.

32. Aderem, A. A., W. A. Scott, and Z. A. Cohn. 1986. Evidence for sequential signals in the induction of the arachidonic acid cascade in macrophages. J. Exp. Med. 163:139-154.

33. Johnson, D. A., J. W. Gautsch, J. R. Sportsman, and J. H. Elder. 1984. Improved technique utilizing non-fat dried milk for analysis of proteins and nucleic acids transferred to nitrocellulose. Gene Anal. Tech. 1:3-8.

34. Van Arman, G., A. J. Beganay, L. M. Miller, and H. H. Pless. 1965. Some details of the inflammations caused by yeast and carrageenin. J. Pharmacol. Exp. Ther. 150:328-334. 